Litovchenko, L. N. (1971). Morfofunktsional'nyye osobennosti yaichnika i yajtsevoda v svyazi s vozrastom i porodoj kur. (Diss. ... kand. vet. nauk). Khar'kov (in Russian)

Masui, K. (1935). Ovariotomy and sex reversal in Brown Leghorn chickens. Botan. Zool. Tokio, 3, 1065-1087.

Scott, H. A. (1974). Follicular development in ovarian transplants in domestic fowl. Br. Poultry. Sci., 15, $235-238$.

Shalduga, N. E. (1967). Kompensatornaya hipertrofiya i reparativnaya regeneratsiya jaichnikov u sel'skokhozyajstvennykh czyvotnych. (Avtoref. diss. ... dokt. vet. nauk). Khar'kov (in Russian)

Song, Y., \& Silversides, F.G. (2006). The technique of orthotopic ovarian transplantation in the chicken. Poultry Sci., 85(6), 1104-1106

Vrakin, V. F., \& Sidorova, M. V. (1984). Anatomiya i histologiya domashnyej ptitsy. Moskva: Kolos (in Russian).

Williams, J. B., \& Sharp, P. J. (1978). Ovarian morphology and rates of ovarian follicular development in laying broiler breeders and commercial egg producing hens. Brit. Poultry Sci., 19(3), 387-395

Zavadovskij, M. M. (1926). Biseksual'naya priroda kuritsy i eksperimental'nyj germafroditizm u kur. Sb. trudov lab. eksperiment. biol. Moskovskoho zooparka, 2, 121-179 (in Russian)

\title{
THE MICROSCOPIC STRUCTURE AND STEREOMETRIC INDICES OF THE OVARIES IN HEIFERS ON RADIATION-CONTAMINATED TERRITORY
}

\author{
T. F. Kot, S. V. Guralska, I. M. Sokulskyi, S. S. Zaika, Z. V. Homenko \\ Zhytomyr National Agroecological University, Zhytomyr, Ukraine \\ Stary Boulevard, 7, Zhytomyr, Zhytomyr region, Ukraine, 10008 \\ E-mail: tkotvet@ukr.net
}

The thesis presents a research of the morphological condition of ovaries of heifers of the black-and-spotted bred of 4 months of age kept on radioactive-contaminated territory. The research has been conducted on the basis of morphological laboratory of anatomy and histology departments of the Zhytomyr National Agroecological University (Zhytomyr, Ukraine). Microscopic, stereometric and statistic methods of research have been applied. The peculiarities of histoarchitectonic and stereometric indices of the microstructures (corticaly and medullary substances, pre-modial, primary, secondary and tertiary follicles, corpus atretic) of the ovaries lited.

Microscopic structure of the ovaries in heifers from the radionuclide contaminated territory and heifers from conditionally clean, not radionuclide contaminated territory are largely similar. Histological studies have established that the ovaries of heifers on cross-section has a corticaly and medullary substances. The absolute volume of the corticaly substance of the ovaries significantly $(p<0.05)$ increases from $2.90 \pm 0.23 \mathrm{sm}^{3}-$ in heifers from not radionuclide contaminated territory to $4.10 \pm 0.32 \mathrm{sm}^{3}$ - in heifers from radionuclide contaminated territory.

The corticaly substance of ovaries represented by loose fibrous connective tissue. In all parts of the corticaly substance it contains pre-modial, primary, secondary and tertiary follicles. Stereometric indexes of microstructures of the follicles is labile indicators and are closely associated with the functional activity of follicles. Follicular atresia proceeds in obliteration type. The process is initiated by multiplication of the blood vessels of the theca follicles and atrophy of the follicular epithelium with simultaneous absorption of the content of the follicles. Nests of epithelioid cells remain in the ovaries as the remnants of such atrophic follicles. They are enclosed by fibrous tissue.

In heifers from the radionuclide contaminated territory absolute volume of the

cavity of follicles, wall of normal follicles, wall of atretic follicles, corpus atretic $(1.04 \pm 0.15$, $0.178 \pm 0.017,0.102 \pm 0.011 \mathrm{sm} \mathrm{m}^{3}$ respectively) significantly $(p<0.05, p<0,01)$ high than this parameters in heifers from conditionally clean, not radionuclide contaminated territory $(0.62 \pm 0.09,0.089 \pm 0.016$, $0.060 \pm 0.008 \mathrm{sm}^{3}$, respectively)

The morphometric research data obtained significantly contribute to the present-day understanding of the morpho-functional state of the reproductive system of animals kept on radiation-contaminated territories.

Key words: cattle, radio-active contamination, ovaries, morphology, stereometry.

\section{МІКРОСКОПІЧНА БУДОВА І СТЕРЕОМЕТРИЧНІ ПОКАЗНИКИ ЯЄЧНИКІВ У ТЕЛИЧОК, ВИРОЩЕНИХ НА РАДІОАКТИВНО ЗАБРУДНЕНІЙ ТЕРИТОРІЇ}

\author{
Т. Ф. Кот, С. В. Гуральська, І. М. Сокульський, С. С. Заїка, 3. В. Хоменко \\ Житомирський національний агроекологічний університет, Житомир, Україна \\ бульвар Старий, 7, Житомир, Житомирська область, Украӥна \\ E-mail: tkotvet@ukr.net
}

Досліджено мікроскопічну будову і стереометричні показники яєчників статевонезрілих теличок чорнорябої породи, вирощених на радіоактивно забрудненій території.

Ключові слова: велика рогата худоба, радіаційне забруднення, яєчники, морфологія, стереометрія 


\section{Вступ}

Актуальність теми. Більше 30 років минуло 3 часу однієї 3 найтрагічніших техногенних катастрофр в історії людства - аварії на Чорнобильської АЕC, яка призвела до забруднення радіонуклідами близько 50 тис. км ${ }^{2}$ території України. Нині вже завершився перший період напіврозпаду основних дозоутворюючих радіонуклідів $\left({ }^{137} \mathrm{Cs},{ }^{90} \mathrm{Sr}\right)$ і продовжують утворюватися нові радіоактивні продукти. $75 \%{ }^{241} \mathrm{Pu}$ перетворилося на ${ }^{241} \mathrm{Am}$, період напіврозпаду якого становить 432 роки (Buzunov, 2006).

Отже, небезпека дії низькоінтенсивного хронічного опромінення на організм людини і тварин не втрачає актуальності. Особливої уваги заслуговує питання морфо-функціональних змін у яєчниках - найбільш радіочутливих органах репродуктивної системи.

Аналіз останніх дослібжень і публікацій. у спеціальній літературі $є$ відомості про раннє статеве дозрівання, зростання частоти гінекологічних хвороб, неплідності, ускладнень перебігу вагітності і родів у жінок, які мешкають на забруднених радіонуклідами територіях. Розглянуто тенденції овогенезу, фолікулогенезу і лютеогенезу. Приведена шкала радіочутливості тканинних елементів яєчників. Обговорені етапи пострадіаційної атрезії фолікулів і суперовуляції яйцеклітин (Buzunov, 2006; Buzunov, 2015; Volosovets, 2018). Літературні дані 3 відтворювальної здатності тварин і радіаційної патології яєчників поодинокі та неповні (Volkivskyi, Revunets, \& Zakharin, 2017; Kot, \& Huralska, 2018).

$$
\text { Завдання }
$$
дослідження: дослідити мікроскопічну будову і стереометричні показники яєчників теличок, вирощених на радіоактивно забрудненій території.

\section{Матеріал і методи досліджень}

Дослідження проводили на кафедрі анатомії і гістології факультету ветеринарної медицини Житомирського національного агроекологічного університету. Матеріалом дослідження були яєчники, відібрані від клінічно здорових теличок $(\mathrm{n}=6)$ чорно-рябої породи віком 4 місяців, вирощених на радіаційно забрудненій (П(ПО)СП «Білокоровичське» Олевського району, дослідна група) і умовно чистій від радіації (СТОВ «Ліщинське» Житомирського району, контрольна група) територіях Житомирської області.

Для проведення гістологічних досліджень застосовували загальноприйняті методи фріксації та виготовлення зрізів [3]. Стереометричні дослідження проводили за алгоритмом M.I. Шкіль (Shkil, 1996). Після встановлення абсолютного об'єму яєчників теличок дослідної $\left(5 \pm 0,28 \mathrm{~cm}^{3}\right)$ і контрольної $\left(4,19 \pm 0,3 \mathrm{~cm}^{3}\right)$ груп визначали відносний і абсолютний об'єми кіркової та мозкової речовини, порожнини фолікулів, залишкової частини кіркової речовини, а також мікроструктур останньої білкової оболонки з поверхневим епітелієм, примордіальних і первинних фолікулів, стінки нормальних і атретичних фролікулів, порожнини фолікулів діаметром до 1-го мм, атретичних тіл, строми. Отримані результати обробляли варіаційностатистичними методами 3 використанням програмного пакету «Statistica 6» для Windows XP.

\section{Результати та їх обговорення}

Мікроскопічна будова яєчників у теличок, вирощених на радіоактивно забрудненій і умовно чистій від радіації територіях, не відрізняеться. На поперечному зрізі яєчників чітко виділяється мозкова і кіркова речовини. 3 них остання займає більшу частку об'єму яєчників - 72,32 $\pm 5,74$ проти $27,68 \pm 2,49 \%$ (контроль) і $82,0 \pm 6,40$ проти $18,0 \pm 2,40$ $\%$ (дослід). Абсолютний об'єм кіркової речовини яєчників у теличок дослідної групи $\left(4,10 \pm 0,32 \mathrm{~cm}^{3}\right)$ на $1,20 \mathrm{~cm}^{3}$ більший $(p<0,05)$ такого показника у теличок контрольної групи $\left(2,90 \pm 0,23 \mathrm{~cm}^{3}\right)$. Щодо абсолютного об'єму мозкової речовини яєчників, у тварин обох груп цей показник майже однаковий -

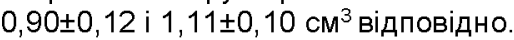

У кірковій речовині яєчників теличок виявлено фолікули - примордіальні, первинні, вторинні, третинні. Фолікули перших двох типів складаються з овоцита, оточеного поодинокими плоскими фолікулярними клітинами (примордіальні фолікули) або їх шаром (первинні фолікули), а також базальною мембраною. У вторинних і третинних фолікулах помітна порожнина з рідиною. Остання відтісняє частину фолікулярних клітин разом 3 овоцитом до одного з полюсів фолікула, утворюючи яйценосний горбок. У сполучнотканинній оболонці фолікулів помітні внутрішня і зовнішня теки. Перша утворена за рахунок гіперплазії фібробластів строми кіркової речовини, складається 3 судинного й залозистого шарів. Судинний шар прилягає безпосередньо до базальної мембрани, містить капіляри і переважно фібробласти. Залозистий шар, окрім капілярів, містить ендокринні клітини. Зовнішня тека утворена фібробластами і міоїдними клітинами.

Порожнина фолікулів у досліджуваних тварин

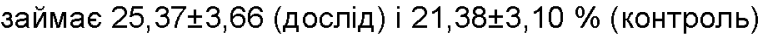
об'єму кіркової речовини яєчників. Абсолютний об'єм порожнини цих фолікулів у теличок дослідної групи $\left(1,04 \pm 0,15 \mathrm{~cm}^{3}\right)$, порівняно з таким показником у теличок контрольної групи $\left(0,62 \pm 0,09 \mathrm{~cm}^{3}\right)$, більший $(p<0,05)$ на $0,42 \mathrm{~cm}^{3}$, що, можливо, пов'язано 3 активізацією фолікулогенезу внаслідок впливу малих доз радіації на гіпоталамо-гіпофрізарногонадну систему тварин (Volkivskyi, Revunets, \& Zakharin, 2017; Kot, \& Huralska, 2018)

Відносний об'єм залишкової частини кіркової речовини яєчників сягає $74,63 \pm 6,59$ (дослід) і $78,62 \pm 6,55 \%$ (контроль). Абсолютний об'єм даної мікроструктури у яєчниках теличок дослідної групи складає $3,06 \pm 0,27 \mathrm{~cm}^{3}$, що на $0,78 \mathrm{~cm}^{3}$ більше $(p<0,05)$ такого показника у теличок контрольної групи $-2,28 \pm 0,19 \mathrm{~cm}^{3}$.

Зовні яєчники теличок вкриті поверхневим епітелієм, представленим одним рядом кубічних клітин. Під ним міститься білкова оболонка, побудована 3 щільної волокнистої сполучної тканини. Відносний об'єм цих мікроструктур у залишковій частині кіркової речовини яєчників

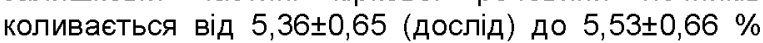
(контроль). Різниця між абсолютним об'ємом білкової оболонки з поверхневим епітелієм $(0,038$ $\left.\mathrm{cm}^{3}\right)$ у яєчниках теличок дослідної $\left(0,164 \pm 0,020 \mathrm{~cm}^{3}\right)$ і контрольної $\left(0,126 \pm 0,015 \mathrm{~cm}^{3}\right) \quad$ груп не вірогідна $(p>0,05)$

Примордіальні і первинні фолікули займають незначний об'єм залишкової частини кіркової

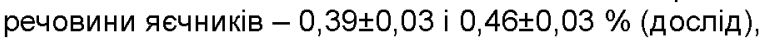




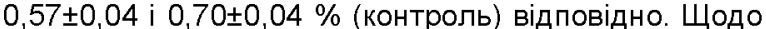
абсолютного об'єму примордіальних і первинних фолікулів, виявлено тенденцію до збільшення даного показника у тварин дослідної групи $0,013 \pm 0,001$ проти $\quad 0,012 \pm 0,001 \quad \mathrm{~cm}^{3}$ 0,016 $\pm 0,001$ проти 0,014 $\pm 0,001 \mathrm{~cm}^{3}$ відповідно.

На порожнину фолікулів діаметром до 1 мм у теличок дослідної та контрольної груп припадає

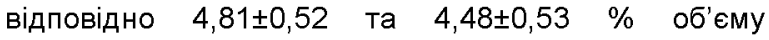
залишкової частини кіркової речовини яєчників. Абсолютний об'єм порожнини даних фолікулів у теличок дослідної $\left(0,089 \pm 0,013 \mathrm{~cm}^{3}\right)$ і контрольної $\left(0,058 \pm 0,008 \mathrm{~cm}^{3}\right)$ груп вірогідно не відрізняється $(p>0,05)$.

Слід відмітити, що у яєчниках досліджуваних теличок на всіх стадіях розвитку фолікулів спостерігається їх атрезія. Причому, вираженість цього процесу прямо залежить від розміру фолікулів, що узгоджується 3 результатами досліджень інших авторів (Kot, \& Huralska, 2018). Ha початку атрезії фолікулів виявляється каріопікноз зернистих клітин в центральних ділянках гранульози. Пізніше некробіотичний процес супроводжується розпушенням і декомплексацією поверхневих клітин гранульози та базальної мембрани. Деструктивні процеси у внутрішній теці на ранній стадії атрезії слабо виражені. Спочатку спостерігається проліферація і набухання текоцитів, внаслідок чого внутрішня тека дещо потовщується, потім відбувається декомплексація і десквамація клітин зернистого шару, дезорганізація та відшарування базальної мембрани від сполучнотканинної оболонки та деформування контура овоцита.

Стінка атретичних фолікулів, на відміну від такої у нормальних, займає більшу частку об'єму залишкової частини кіркової речовини яєчників

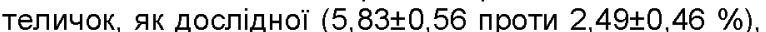
так і контрольної $(3,91 \pm 0,70$ проти $1,71 \pm 0,31 \%)$ груп. Щодо абсолютного об'єму стінки атретичних фолікулів, цей показник у теличок дослідної групи $\left(0,178 \pm 0,017 \mathrm{~cm}^{3}\right)$, порівняно з таким у теличок контрольної групи $\left(0,089 \pm 0,016 \mathrm{~cm}^{3}\right)$, вірогідно $(p<0,01)$ збільшується на $0,090 \mathrm{~cm}^{3}$

Завершення морфогенезу атрезії вторинних і третинних фолікулів у яєчниках досліджуваних тварин відбувається за облітераційним типом. Після глибоких деструктивних змін у зернистому шарі 3 боку зовнішньої теки розростається молода грануляційна тканина з новоутвореними капілярами. Вона поступово заміщує фолікулярну рідину та структурні компоненти фолікула. На місці останніх поступово утворюються атретичні тіла. Вони займають у яєчниках теличок дослідної і контрольної

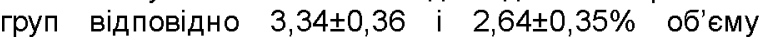
залишкової частини кіркової речовини. Абсолютний об'єм атретичних тіл у яєчниках теличок дослідної групи $\left(0,102 \pm 0,011 \mathrm{~cm}^{3}\right)$, відносно такого показника у теличок контрольної групи $\left(0,060 \pm 0,008 \mathrm{~cm}^{3}\right)$, вірогідно $(p<0,05)$ зростає на $0,042 \mathrm{~cm}^{3}$.

На строму у теличок дослідної і контрольної груп припадає найбільша частка об'єму залишкової

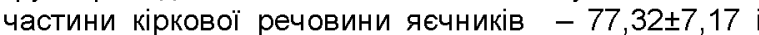
$80,46 \pm 6,76 \%$ відповідно. Щодо абсолютного об'єму строми, встановлено тенденцію до його збільшення

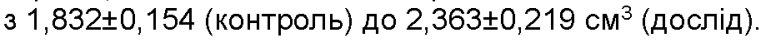

Таким чином, порівняльний підхід до вивчення будови яєчників у теличок, вирощених на радіоактивно забрудненій і умовно чистій від радіації територіях, дав можливість з'ясувати особливості мікроструктури та встановити відмінності стереометричних показників структурних елементів.

\section{Тривале малоінтенсивне іонізуюче} випромінювання не впливає на загальний план мікроскопічної будови яєчників теличок. Його дія проявляється збільшенням показників абсолютного об'єму кіркової речовини (на $1,20 \mathrm{~cm}^{3}$ ), порожнини фолікулів (на 0,42 $\mathrm{cm}^{3}$ ), стінки атретичних фолікулів (на $0,090 \mathrm{~cm}^{3}$ ), атретичних тіл (на $0,042 \mathrm{~cm}^{3}$ ), що свідчить про більш інтенсивний ріст і розвиток яєчників та посилену морфофункціональну активність структурних компонентів кіркової речовини, особливо фолікулів на більш пізніх стадіях свого розвитку.

Перспективи подальших досліджень. Для вивчення інтенсивності білкового і вуглеводного обмінів у яєчниках теличок планується провести гістохімічні дослідження на виявлення і локалізацію сульфатованих глікозаміногліканів, глікогену, нейтральних глікопротеїдів, основних та кислих білків.

\section{References}

Buzunov, V. A. (2006). Epidemiolohiia nepukhlynnykh efektiv ionizuiuchoho oprominennia. Zhurnal AMN Ukrainy. 12(1).174-184 (in Ukrainian).

Buzunov, V. A. (2015). Pisliaavariini zminy stanu zdorovia uchasnykiv likvidatsii naslidkiv avarii na ChAES. Problemy radiatsiinoi medytsyny ta radiobiolohii, 20, 157-173 (in Ukrainian).

Goralsky, L. P., Khomich, V. T., \& Kononsky, O. I. (2005). Osnovy histolohichnoi tekhniky i morfofunktsionalni metody doslidzhen u normi ta pry patolohii. Zhytomyr: Polissya (in Ukrainian).

Volkivskyi, I. A., Revunets, A. S., \& Zakharin, V. V. (2017). Vidtvorennia velykoi rohatoi khudoby $\vee$ hospodarstvakh Zhytomyrskoi oblasti. Visnyk Zhytomyrskoho natsionalnoho ahroekolohichnoho universytetu. 1(60). 166-173 (in Ukrainian).

Volosovets, O. P. (2018). Postchornobylski trendy u poshyrenni khvorob ta zakhvoriuvanosti dytiachoho naselennia Ukrainy. Svit medytsyny ta biolohii, 2(64), 15-23 (in Ukrainian).

Kot, T. F., \& Huralska, S. V. (2018). Osoblyvosti morfolohii yaiechnykiv telyts, vyroshchenykh na zabrudnenii radionuklidamy terytorii. Zbirnyk naukovykh prats "Chornobylska katastrofa. Aktualni problemy, napriamky ta shliakhy yikh vyrishennia». Zhytomyr. 195-198 (in Ukrainian).

Shkil, M. I. (1996). Vykorystannia systemnoi stereometrii dlia morfo-funktsionalnoi kharakterystyky yaiechnykiv telyts koriv. Aktualni pytannia veterynarnoi patolohii: Materialy / Vseukrainska naukovo-vyrobnycha konferentsiia veterynarnykh patolohiv. Kyiv. 273-238 (in Ukrainian) 